\title{
ICT and its purpose in the pedagogical practice
}

\author{
Diego Enrique Báez Zarabanda* \\ University of Granada \\ dbaez3@unab.edu.co \\ *Corresponding Author: dbaez3@unab.edu.co \\ Received : 04.07.2019 \\ Revision Requested: 09.08.2019 \\ Accepted : 25.09 .2019
}

How to cite this paper: Zarabanda, D. E. B. (2019). ICT and its purpose in the pedagogical practice. Research in Social Sciences and Technology, 4(2), 83-95.

\begin{abstract}
Information and communications technology (ICT) is currently inserted in the daily activities of a human being and has become a necessary resource, vital for their development up to the point of not conceiving activities without using these. In this sense, the education field is not the exception and has been partially including ICT as support for the teaching practice; however, there is an increasing demand from the students to implement more resources and activities supported by these technologies. A significant distance exists (the known digital divide) between the possibilities offered by different web applications that can support the pedagogical practices and the actual reality of the teaching practice, where the students realize the flaws and the necessity of strengthening the technology skills of the teachers to efficiently develop and orientate such use. In this regard, it is necessary to critically reflect on the possibilities that are offered by different web applications and their impact, their purpose in the pedagogical practice in a way that can serve as a pretext to motivate the teachers in their use and application in the development of their classes, achieving real formative processes. By doing this, students can be offered real, significant learning experiences from the technological, social, and pedagogical view, consolidating in a first instance the abilities of the teachers in the ICT area, as well as the comprehensive learning of their students, being updated on the advances that ICT offers globally, and implementing these permanently in their job as teachers, thus innovating their classes and motivating students towards learning and toward consolidating the use of ICT in the different disciplines, with the human and social component that must characterize us, accomplishing from this standpoint and reflection a pedagogical practice of quality.
\end{abstract}

Keywords: ICT, pedagogical practice, Digital competences, Teacher, Educational institution. 


\section{Introduction}

Considering the different pedagogical, psychological, religious, and political stances from which a class can be boarded, different strategies and efforts have been proposed for the duty of the teacher throughout history, which are considered to be the focus of the functioning of educational institutions and pedagogy (understanding pedagogy as the development of the education process, that is to say the class itself). These strategies have looked for alternatives to generate through education better human beings, a better society; however, from other scenarios and perspectives, on the contrary, school has been held responsible for the flaws and deterioration of society. In this regard, Tenti (1994) states that "the educational system, despite its unfulfilled promises, constitutes an institutional network that contributed significantly to the social democratization process" and, in the order mentioned above, gives relevance to the role of educational institutions in the society.

In fact, it is clear that school has a transcendental function in individuals' development and their environment, and that around school is where future professionals are guided with the necessary abilities to address the challenges of the current society. Among these great challenges, the intersection between ICT and its use in the permanent qualification of pedagogy is found. However, although most educational institutions (in all levels) work toward "comprehensive education for its students," many of these focus their models, strategies, activities, and resources in subjects that are disciplinary only. In many of the courses and class subjects that identify the educational institution, ICT has a secondary role and is even invisible in the practice of pedagogy. As Torío (2004) affirms, "we live in a period in which traditional institutions are not able to transmit values and behavior patterns with decisive solvency" ( $p$. 39).

Each semester or annually, educational institutions graduate high school students or undergraduate students with disciplinary abilities in the different areas of education, ruled by national and international standardized tests (PISA, TALIS, PIRLS, TIMSS), which position the educational institutions giving these the label of "quality entities" and placing them in the different rankings. This classification conditions the educational institutions toward generating strategies and giving resources to the disciplinary within their classrooms or academic spaces, considering the areas where these international tests evaluate them. In that sense, ICT and the role it must execute in pedagogy are not being used at its full potential, on one hand because the national and international tests do not evaluate rigorously the technological abilities of the students, and on the other hand because, based on years of teaching experience in the private and public sector, as well as in diverse researches, there are flaws in the technological abilities of the teachers from different areas when implementing ICT in pedagogy or even in the educational policies established by the institution, by secretaries or by the Ministry of Education. These competences, which teachers must possess for the most effective and efficient incorporation of ICT in their pedagogical practice, according to Cabero (2014), are: 
Cognitive (knowledge of their discipline), technique (ICT domain), pedagogical applications (knowledge of the possibilities they offer as educational tools), methodological (application of appropriate procedures), positive and critical attitude towards them, facilitator of the teachinglearning process, of the ability for their students to incorporate them into their learning, of the ability to adequately choose technological resources, of being permanently trained and trained in their use, ability to work cooperatively in networks, and of being a constant evaluator. (p. 114)

Also, some of the technological inclusion policies in the educational institutions are exclusively focused on "supplying schools with technological resources that are centralized in computer rooms with internet access" (Moreira, 2011, p. 51), originating on the one hand a latent reality where technological resources for classes exist but are used almost exclusively by teachers from the computing areas, and on the other hand, the lack of technological abilities of the teachers or, in some cases, the resistance to using the many existing applications to make pedagogy dynamic, create a situation that goes against the possibilities of ICT in the consolidation of significant learning experiences where both the student and the teacher can constitute and strengthen conceptual and procedural use frameworks, the manipulation and use of web resources (online and offline) offered independently from the area of education.

Considering this, Cassany (2006) refers to the need of incorporating ICT into the educational environment, stating that:

The kids from today will be adults in 2020. What use is learning to write only in pencil and paper? The kid is sitting in class on Tuesday morning, writing with pencil..., what motivation does the kid have to write like this? What is the kid feeling? What do the kids think, if at home they have broadband (Wi-Fi), if when they lift their head up they see through the window an employee of the company, sitting in front of an amazing flat screen, with spell check, style corrector, and an assisted translation program? For the kids of today, the adults of tomorrow, reading and writing should already be using websites, elaborating hypertexts, composing emails, conversing or chatting through spell check and translating programs, besides taking notes with paper and pencil and reading books with hard covers. (p. 183)

Therefore, in most educational institutions, students are still being isolated from ICT and its possibilities.

Also, in the development of pedagogical practices, the educational institutions have the identity and application of the four pillars of education (Delors, 1996), but in the real execution of academic activities, the institutions give more priority and resources to knowing rather than doing, considering the areas covered by national and international standardized tests. However, in none of these measures of "comprehensive education" and/or "educational quality" is it possible to evaluate what kind of human beings they are educating, what their ethics will be as professionals and in their personal lives in diverse situations in the future, making decisions 
that could undoubtedly affect (positively or negatively) their environment, more than the abilities and disciplinary competences learned within the educational institution.

Similarly, McKinsey (2007) showed that educational investment vs. results on standardized tests is not a sin qua non condition. For example, "Singapore, one of the countries with best performance in the world, spends less on primary education than 27 out of the 30 countries of the OCDE" (p. 6). An aspect this demonstrates is not investment necessarily but the way pedagogical practices are performed to achieve disciplinary competences. Using Inger Enkvist's words, "What the PISA tests evaluates do not reveal if there is a good environment in the classrooms, good principles are taught or if humanities are well taught." Therefore, high results on standardized tests are not precisely a guarantee for the institution, and even less to society, that the objective of "comprehensive learning" is being accomplished; also, it cannot guarantee the minimization or elimination of the current index of corruption, violence, or any other social indicators that show the defects of the education system.

\section{ICT in education}

Historically, in many law postulates and models it is established that education must supply the current needs of society and construct citizens to face the challenges of the future. This is even more important in a time of globalization and immersion in the knowledge society, the ICT, and when many human activities have been automatized. New generations must get the necessary competences to perform in this new context. Regarding this, as stated by Bernete (2012), "For young people, using internet or SMS is something as natural as for their parents is watching TV of for their grandparents is listening to the radio. We know that each generation and social group 'naturalizes' the technologies that are available and tries to benefit from it" (p. 98).

In this sense, technological inclusion must be "naturally" introduced in the pedagogical practices, the teacher being the leader in the areas of planning, organizing, and developing, as in the abilities of managing different web tools and their application in academic process and even social processes based on the institutional and area goals, in their interests and needs of the context.

Nevertheless, the incorporation of ICT in the educational area has been given "unequally and in occasions with restrictive and limited means despite the existing consensus about their value as tools of great help in the development of the learning process" (González, 2007, p. 221), leading to many of the pedagogical practices mentioned previously, which must be a task for all educational professionals who dedicate to this labor, to give relevance to the importance of ICT in education (Yucel et al., 2010).

In fact, ICT has been incorporated almost completely in the daily activities of the human being, including an important place in leisure and free time. The everyday nature of the students goes by in social media, chats, internet searches, online games, everything within one click; kids and 
teenagers today are "digital natives," but "ICTs are still absent in most classrooms or academic spaces, and when they are not, a great part of the teacher practices are still reluctant to their usage" (Moreira, 2011, p. 51). This is why it is necessary that teachers as mediators of the learning process recognize this reality and its implication in the way of being, learning, and interacting of this new generation, to link said dynamics in the pedagogical practice and exploit its potential.

In relation to these new learning dynamics and the everyday nature of our current students, according to Moreira, Machado, and Santos (2015):

For this generation of Millennials, the use of technology, internet, phones and videogames constitutes an undeniable referent for their daily life; without technology Millennials are isolated from their social group and also without the possibility of developing activities such as leisure or interpersonal communication. In that sense, those kids disconnected from the internet are excluded from a social interaction circle that makes part of the everyday life of a whole generation. (p. 13)

Not using ICT in educative processes, and even preventing students from using pedagogical practices, would be ignoring this reality; teachers must use this knowledge to potentialize and focus those technological abilities towards the cognition development and strengthening in the different disciplines, giving students benefits since they use these tools in the social arena, games, and in their free time.

Despite their immersion in the digital world, students are not experts or wholly responsible (due to their age and chronological maturity) in the use and manipulation of the information found on the internet; on the contrary, they have limitations to identify and critically manage the information found, as affirmed by Cassany (2006): "On the internet you can find everything that humans are able to produce, no censorship, no limits, no frontiers... On the internet the garbage and the mud are mixed with the pearls and jewels" (p. 220). It is necessary to build in students the ability to filter information and evaluate it, discriminating the scientific from the speculative, the trustworthy websites from those without academic foundations, and educate them with disciplinary and technological judgement to know how to navigate through abundant information, since "the difficulty resides in how to select, interpret and evaluate the information that surrounds us" (Gonzalez, 2007, p. 221).

\section{ICT and pedagogical practice}

Based on the aforementioned approaches, the path which pedagogical practices in educational institutions should walk glimpses how ICTs are exploited by the education community and achieve the formative function in the disciplinary and social areas, since "alphabetization in the digital culture must be understood and something more complex that the mere learning of using social software tools or tools from web 2.0" (Moreira, Machado, \& Santos, 2015, p. 30), 
placing the teacher at the center of this alphabetization process, responsible for the adequate use of the outnumbered tools currently offered by different platforms and web applications, and as stated by Moreira, not only using the applications in class, for in this respect the Millennial student possesses an advantage over the teacher; the teacher must print the pedagogic manuals of these, with objectives clearly planned, established in order to use ICT to its full potential (Tarman, Baytak, \& Duman, 2015). In other words, as stated by Perez Gomez (2013), "Equity in access and training for critical knowledge are the two faces of alphabetization in the use of digital technologies. Therefore, different authors pose the need for education to radically rethink their objectives and formative competences to be an educated, critical and democratic civilian in the new illustration that the digital culture represents."

Due to this, educational institutions are called upon for real changes in their processes, and in the transformation of their teachers, to redesign pedagogical practices based on the current needs: the incorporation of ICT in education, since it is the reality, interest, and necessity of the students. However, using web applications or technological tools cannot be reduced to digitalizing activities and traditional proposals, papering over traditional teaching methods with new technologies; although ICT is a facilitating, motivating tool that also supports the development of pedagogical practices more appropriately, its success is determined by the pedagogical use given by the teacher. In terms of Cuban (2006) cited by Moreira (2011), "technology is not the motor of innovations, but the didactic methodologies for the use of these" (p. 60).

In relation to the pedagogical use of ICT, it is useful to cite Sabada and Bringue (2010), who identify the main characteristics of kids and teenagers in relation to the use of ICT, and that it is necessary that teachers refer to ICT both in the planning as well as in the development of their classes, to adjust, make flexible, and lead their pedagogical practice to a good use. According to Sabada and Bringue (2010), the characteristics of Millennials in relation to the use of ICT are:

- Equipped: They have access to an ample range of technological devices.

In this aspect, the teacher must manipulate a wide range of devices to provide students with the specific discipline of study.

- Multitask: They perform various tasks simultaneously, even using the availability of various screens; for example, watching TV while navigating the internet or making a phone call.

Regarding this characteristic, there is an important challenge for the teacher and the digital immigrant; multitasking is not easy if it is not permanently practiced with the use of devices and applications to strengthen this ability.

- Mobilized: By age 12, kids already have phones available.

Here is where the gap between teachers and students widens, and while for students it is easier to recognize and use new tools or applications, for the teacher this can become a complex task. Therefore, the challenge and compromise for teachers is to be permanently updated in the use of devices and their applications.

- Interactive: They prefer the interactivity offered by the internet rather than TV. 
Although it is true that TV can support practical pedagogy, it is possible that through the use of other devices or applications, the demand from the student for interactivity can be supplied.

- Emancipated: In the home context, they use their own screens, which allows them to be more independent in relation to the use of technology and the consumption of information.

This subject can be complex, considering many realities around the social and economic circumstances of our students and the educational institutions. Many students and their families have devices at home, but it is possible that these have to be shared, or the internet connection is not of good quality. This reality is not exogenous to the ordinariness and dynamic of the institutions and with which the teacher must interact daily to offer their students a significant and quality pedagogical practice.

- Autonomy: Between 10-18 years old, more than half are alone when watching TV, playing videogames, or navigating the internet.

This last characteristic points to an important challenge and compromise from the teacher and the educational institution regarding digital and social responsibility that must be developed and strengthened continuously in the students in order for them to be conscious about their actions and how these can affect themselves and others.

In relation to digital responsibility, due to the immersion of ICT in daily life, a relevant aspect emerges when it comes to educating students: the security in digital competences "to encourage participation and empowerment of the society of the $21^{\text {st }}$ century. Promoting them, implies the critical, creative and secure use of the ICT, either with work, school or activities of daily life purposes" (Castillejos, Torres, \& Lagunes, 2016).

Castillejos, Torres, and Lagunes (2016) specifically affirm that:

The security subject is not only centered in protecting the user and its devices, but also boards the relative to the protection of the natural environment. It gives awareness about the acquisition of devices, the use of energy, recycling and disposal of devices, as well as the appropriateness of digital tools to promote care for the environment and the use of green technologies.

In that sense, the National Institute of Educative Technologies and Professors Education (INTEF, 2014) considers the level of security a series of competences that the teacher must know and apply in a way that can educate students about their importance. Such competences are:

Table 1. Security, digital competence area.

COMPETENCE DESCRIPTION

\begin{tabular}{ll}
\hline Device protection & $\begin{array}{l}\text { Protect the devices and understand the risks and threats of the web; } \\
\text { know protection and security measures. }\end{array}$ \\
Protection of personal data & $\begin{array}{l}\text { Understand the usual terms of use of the programs and digital } \\
\text { services; actively protect personal data; respect the privacy of others; } \\
\text { protect yourself from threats, frauds and harassment. }\end{array}$
\end{tabular}




\begin{tabular}{ll}
\hline Health protection & $\begin{array}{l}\text { Avoid health risks relating to use of technologies regarding threats of } \\
\text { physical integrity and psychological well-being. }\end{array}$ \\
Environment protection & Considering the impact of ICT in the environment.
\end{tabular}

Source: INTEF 2014.

Based on this description, the teacher must teach these competences in the subject of digital security for the benefit of students and the education community. INTEF (2017) defines the digital competence as "the creative, critical and secure use of the technologies of information and communication to achieve the objectives related to work, employability, learning, free time, inclusion and participation in society" (p. 12).

INTEF presents in its document "Common framework of digital competence of teachersSeptember 2017" the areas of competence in which the teacher must be skilled with technologies and show these skills in their pedagogical practice. This way, ICT can be used to its full potential through the leadership of the teacher in different scenarios and situations that can arise in the development of an academic exercise. These areas of competence are:

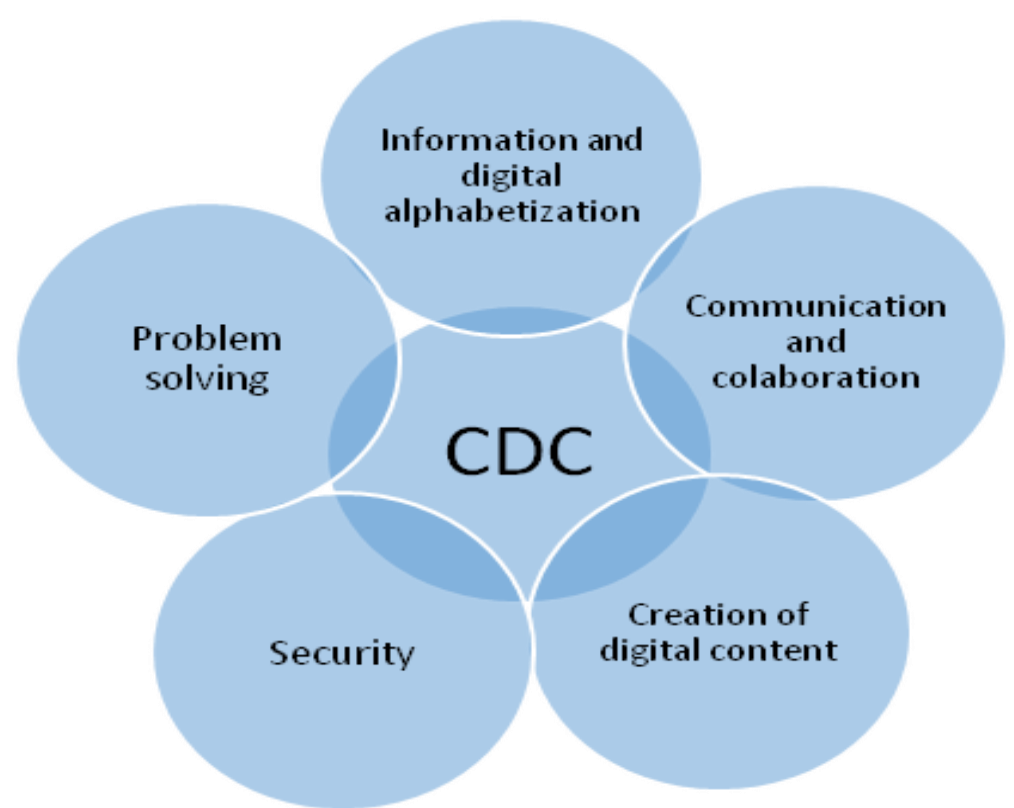

Figure 1. Common Framework of digital competence of teachers (CDC). Source: Adapted from areas of the Common Framework of Digital Competence of Teachers-INTEF (2017)

Referring to this classification, the five areas contemplate a specific number of competences each, adding 21 that are also subdivided in six levels of competence differentiated by INTEF $(2017$, p. 3) as the following:

The Common Framework of Digital Competence of Teachers establishes three dimensions in each of the competences of the five areas that compose it. The first dimension is basic and 
includes levels $A 1$ and $A 2$. The second dimension is intermediate and includes levels B1 and B2. Lastly, the third dimension is advanced and includes level C1 and C2. This structure is designed to identify the level of digital competence of teachers, establishing a progressive level of development and autonomy from level A1 to the highest level, C2.

Based on this, teachers can demonstrate their current level of digital competence, making relevant the insertion of ICT in their pedagogical practice and the optimal pedagogical and didactic use of these tools.

Therefore, we must permanently reflect in our duty as teachers, training frequently about new applications and possibilities that surge for the qualification of our labor in the disciplinary area as well as in the social arena. It is the teachers' moral and professional responsibility for ICT to not be underused and be able to offer the students everyday what Báez (2019) has denominated "significant learning experiences (SLE)," which are comprised of the following aspects:

- Generate spaces for students to acquire their knowledge in knowing, knowing how, and social and civil competences; through activities of practical character that give place to cooperative work, solidarity, in the staging of values and principles, constructing from these at the same time the necessary knowledge to confront problems that emerge from the epistemological rigor that the level of study requires.

- For it to be significant, it must consider the disciplinary and social need in the personal environment of the student and the community. Similarly, the manifested interests by students in the development of classes must be shown in planning and teacher activities, in a way that they can feel an active part of the education process.

- Learning, a product of the first two, since these develop in scenarios where the students "do what they want" and see a relationship, the pertinence of it with real life outside school or university, will allow in a more effective manner to achieve noteworthy learning for their professional exercise or their performance as citizens and as part of a family of a community in the two postulated and argued areas: disciplinary and axiological. (p. 35)

This means that the teacher must be updated on the technological aspects, web applications, and having high digital abilities, because "even regular users of new technologies ignore the didactic potential and the possible ways of including these in the curriculums of obligatory learning" (Gutierrez, Palacios, \& Torrego, 2010), but also in the emotional, axiological, and ethic aspects, in their behavior and the synergy they reach with their students, the resilience of the teacher, giving real meaning to life from the disciplinary and behavioral learnings achieved in its students and future citizens of the world with the support of ICT. "Digital technologies are not only an instrument or machines that we have added to our daily lives, but these have controverted in the necessary and indispensable prosthesis to coexist and connect with others, 
to work, to shop, to do management processes, to have fun..., or for any other social action of the $21^{\text {st }}$ century" (Moreira, Machado, \& Santos, 2015).

The teacher must assume the role, considering this new reality, this new "prosthesis" the students have inside and outside the classroom, to continuously improve pedagogical practices and strengthen the four pillars of knowing, doing, being, and coexisting (Delors, 1996) through the mediation and support of ICT. 


\section{References}

Báez, D. (2019). El deber ser de las instituciones de educación media y superior sobre su responsabilidad en la formación integral del ser humano. In M. El Homrani, S. Arias, and I. Ávalos (Eds.), La inclusión, una apuesta educativa y social (pp. 27-37). Spain: Editorial Wolters Kluwer.

Baumman, Z. (2006). Modernidad líquida. Buenos Aires: Fund of Economic Culture.

Bernete, F. (2010). Usos de las TIC, Relaciones sociales y cambios en la socialización de las y los jóvenes. Revista de Estudios Juveniles, 88, 97-114.

Cabero, J. (2014). Formación del profesorado universitario en TIC. Aplicación del método Delphi para la selección de los contenidos formativos. Educación XX1, 17(1), 111-132. doi: 10.5944/educxx1.17.1.10707. Available from http://www.redalyc.org/pdf/706/70629509005.pdf

Cassany, D. (2006). Tras las líneas. Barcelona, Spain: Anagrama Editorial.

Castillejos, B., Torres, C., \& Lagunes, A. (2016). La seguridad en las competencias digitales de los millennials. Apertura (Guadalajara, Jal.), 8(2), 54-69. Available from http://www.scielo.org.mx/scielo.php?script=sci_arttext\&pid=S1665$61802016000300054 \& \operatorname{lng}=e s \&$ tlng=es

Delors, J. (1996). Los cuatro pilares de la educación. En: La educación encierra un tesoro. Report to UNESCO of the International Commission on Education for the 21st Century. Available from http://www.unesco.org/education/pdf/DELORS_S.PDF

Enkvist, I. (2010). El éxito educativo finlandés. Bordón. Revista Pedagogía, 62(3), 49-67.

Enkvist, I. (2012). La buena y la mala educación: Ejemplos internacionales (Vol. 454). Encuentro.

González, M. (2007). Las TIC como factor de innovación y mejora de la calidad de la enseñanza. In J. Cabero (Ed.), Tecnología educativa, (pp. 219-232). Madrid: McGrawHill.

Gutiérrez, A., Palacios, A., \& Torrego, L. (2010). La formación de los futuros maestros y la integración de las TIC en la educación: Anatomía de un desencuentro. Revista de Educación, 352. Available from http://www.revistaeducacion.educacion.es/re352/re352_TIC.pdf 
INTEF (2014). Marco común de competencia digital docente. Available from http://educalab.es/documents/10180/12809/MarcoComunCompeDigiDoceV2.p df

INTEF (2017). Marco común de competencia digital docente. Available from http://eduteka.icesi.edu.co/pdfdir/intef-competencia-digital-docente-2017.pdf

McKinsey. (2007). Cómo hicieron los sistemas educativos con mejor desempeño del mundo para alcanzar sus objetivos. McKinsey Global Institute. Available from: https://www.oei.es/historico/pdfs/documento_preal41.pdf

Moreira, M. (2011). Los efectos del modelo 1:1 en el cambio educativo en las escuelas. Evidencias y desafíos para las políticas iberoamericanas. Revista Iberoamericana de Educación, 56, 49-74.

Moreira, M. A., Machado, J. F. B., \& Santos, M. B. S. N. (2015). Educar a la generación de los Millennials como ciudadanos cultos del ciberespacio: Apuntes para la alfabetización digital. Revista de Estudios de Juventud, (109), 13-32.

Muñoz \& González. (2009). El diseño de materiales de aprendizaje multimedia y las nuevas competencias del docente en contextos teleformativos. Available from https://books.google.com.co/books?id=oegsuFHM5tMC\&printsec=frontcover\&hl=es\# $v=$ onepage $\& q \& f=f a l s e$

Nevid, J. (2011). Teaching the millennials. APS Observer, 24(5).

Pérez Gómez, A. (2013). Educarse en la era digital. Madrid: Morata.

Prensky, M. (2010). Nativos e inmigrantes digitales. Available from http://www.marcprensky.com/writing/PrenskyNATIVOS\%20E\%20INMIGRANTES\%20DIGITALES\%20(SEK).pdf

Roblizo Colmenero, M. J., \& Cózar Gutiérrez, R. (2016). Usos y competencias en TIC en los futuros maestros de educación infantil y primaria: Hacia una alfabetización tecnológica real para docentes. Revista de Medios y Educación, 47, 23-39. Available from https://recyt.fecyt.es/index.php/pixel/article/view/61669/37680

Sádaba, Ch., \& Bringué, X. (2010). Niños y adolescentes españoles ante las pantallas: Rasgos configuradores de una generación interactiva. CEE Participación Educativa, 15, 86-104. Available from http://www.mecd.gob.es/revista-cee/pdf/n15-bringue-sala.pdf 
Tarman, B., Baytak, A., \& Duman, H. (2015). Teachers' views on an ICT reform in education for social justice. Eurasia Journal of Mathematics, Science and Technology Education, 11(4), 865-874. Doi: 10.12973/eurasia.2015.1445a

Tenti Fanfani, E. (1994). La escuela vacía: Deberes del estado y responsabilidades de la sociedad (No. 37.014). Unicef. Available from https://bit.ly/2mge1yA

Torío López, S. (2004). Familia, escuela y sociedad. Aula Abierta, 83.

Yucel, C., Acun, I., Tarman, B., \& Mete, T. (2010). A model to explore Turkish teachers' ICT integration stages. Turkish Online Journal of Educational Technology, 9(4), 1-9. 